\title{
DAMPAK KEBERADAAN PERUSAHAAN AIR MINUM DALAM KEMASAN DI KLATEN-JAWA TENGAH PADA SITUASI PEREKONOMIAN MASYARAKAT (Impact of Presence of Botled Drinking Water Corporation in Klaten-Central Java on Economic Situation of Community)
}

\author{
Joko Mariyono ${ }^{1}$ dan Muhammad Atiq Zambani ${ }^{2}$ \\ ${ }^{1}$ Program Pascasarjana, Universitas Pancasakti, Jl. Halmahera km-1 Tegal, Jawa Tengah. \\ ${ }^{2}$ PT Tirta Investama, Jl. Cokro-Delanggu km-1 Klaten, Jawa Tengah. \\ *Penulis korespondensi. No Tel/Fax: 0283 355720. Email: mrjoko28@gmail.com.
}

Diterima: 31 Agustus 2014

Disetujui: 4 Maret 2015

\begin{abstract}
Abstrak
Keberadaan sebuah perusahaan akan berpengaruh pada masyarakat sekitar. Kajian ini menganalisis dampak ekonomi perusahaan air minum dalam kemasan di Kabupaten Klaten terhadap kehidupan masyarakat di sekitar perusahaan. Data dikumpulkan dengan wawancara pada 300 rumah tangga. Wawancara berdasarkan kuesioner yang terstruktur. Analisis dilakukan pada pendapatan rumah tangga, konsumsi dan investasi pendidikan anak. Analisis data menggunakan model pertumbuhan dan pengambilan keputusan, yang diestimasi dengan model ekonometrik. Hasil analisis menunjukkan bahwa keberadaan perusahaan telah memperbaiki kehidupan masyarakat di sekitar perusahaan. Keberadaan perusahaan telah meningkatkan pendapatan yang cepat sehingga dapat mengejar tingkat pendapatan masyarakat lain yang lebih sudah lebih baik. Sebagai akibat kenaikan pendapatan yang cepat, konsumsi keluarga meningkat dan mendorong investasi pendidikan anak. Investasi pendidikan anak sangat penting karena merupakan usaha untuk meningkatkan sumberdaya manusia. Generasi penerus yang terdidik dan berkualitas akan menentukan pembangunan bangsa. Meskipun keberadaan perusahaan telah berdampak positif bagi perekonomian masyarakat sekitar, perusahaan tidak serta merta dapat mengexploitasi sumber daya air tanpa batas. Perusahaan masih harus bertanggung jawab untuk melakukan konservasi lingkungan agar penggunaan sumber daya air tetap lestari dan bermanfaat bagi masyarakat.
\end{abstract}

Kata kunci: dampak ekonomi, investasi pendidikan, perusahaan air minum dalam kemasan, metode kuantitatif.

\begin{abstract}
The existence of a corporation will affect the surrounding community. This study analyzes the economic impacts of the presence of the botled drinking water corporation in Klaten District on the livelihood of people around the firm. Data were collected by interviewing 300 households. Interviews were based on a structured questionnaire. Analysis was conducted on household income, consumption and education investment of children. Income growth and decisionmaking models were used and estimated using econometric models. The results show that the presence of company has been improving the livelyhood of people around the company. Family income has increased and levelled others with higher income levels. As a result of the rapid increase in income, household consumption increased and encouraged education investment. The education of children is important because it attempts to improve the quality of human resource. The next educated and qualified generation determines development of the nation. Although the presence of company has provided desirable economic impacts on the community, it does not immediately mean that the company can extract water resource without limitation. The company still has responsibility to conserve the environment such that the use of water resource is sustainable and benefits community.
\end{abstract}

Keywords: botled drinking water corporation, economic impact, education investment, quantitative method.

\section{PENDAHULUAN}

Keberadaan sebuah perusahaan di tempat yang baru sudah pasti akan memberikan pengaruh terhadap kondisi sosial-ekonomi masyarakat sekitar, baik secara langsung maupun tidak langsung. Keadaan ini yang sering disebut sebagai eksternalitas. Dampak langsung dapat berupa kegiatan eknomi perusahaan, baik dari segi proses produksi dan pemasaran produk akhir. Dari sisi proses produksi, perusahaan akan memerlukan pasokan input material dan input tenaga kerja. Dari sisi produksi, perusahaan juga memerlukan moda transportasi beserta tenaga kerjanya. Secara tidak langsung, kegiatan tersebut akan menghasilkan efek pengganda ekonomi, dalam bentuk kesempatan dan lapangan kerja informal, misalnya warung makan, sewa rumah, dan angkutan lokal.

Secara sengaja, perusahaan tertentu menyisihkan sebagian keuntungan bersih perusahaan dalam bentuk Corporate Social Responsibility (CSR). CSR didefinisikan sebagai proses operasi bisnis yang dilakukan berdasarkan kepatuhan terhadap persyaratan dan ketentuan 
hukum yang berlaku, dan sesuai dengan nilai-nilai etika suatu bisnis. CSR merupakan praktek bisnis yang terbuka dan transparan, yang didasarkan pada nilai-nilai etika dan menghormati karyawan, masyarakat dan lingkungan. Hal ini bertujuan untuk memberikan nilai yang berkelanjutan bagi masyarakat pada umumnya dan pemegang saham pada khususnya (Anonim, 2006). Konsep CSR didasarkan pada gagasan bahwa selain pemerintah, perusahaan juga harus bertanggung jawab terhadap masalah sosial yang terjadi. Dengan pendekatan yang modern, CSR dipandang sebagai sebuah konsep yang dilaksanakan atas dasar sukarela terhadap masalah sosial dan lingkungan, yang terintegrasi dalam operasi bisnis perusahaan dan dalam interaksi dengan pemangku kepentingan. Perusahaan bertanggung jawab secara sosial karena berinvestasi dengan memanfaatkan sumber daya manusia dan lingkungan (Chahoud dan Emmerling, 2006).

CSR berguna bagi perusahaan dan masyarakat. Dari sisi perusahaan, CSR mampu meningkatkan nilai perusahaan (Meutia, 2005), yang artinya bahwa CSR merupakan faktor yang mempengaruhi nilai perusahaan tinggi atau rendah. Semakin banyak perusahaan mengungkapkan sumbangan sosialnya maka akan semakin tinggi nilai perusahaan (Gunawan dan Utami, 2008). Hal ini didukung oleh fakta bahwa CSR telah meningkatkan performa perusahaan (Comincioli dkk., 2012; Kotler dan Lee, 2005). Lebih lanjut, CSR dapat memberikan manfaat kepada masyarakat (Soesilowati dkk., 2011) dan dapat membantu dalam mengentaskan kemiskinan (Prayogo dan Hilarus, 2012). Hal yang penting untuk dicatat adalah bahwa CSR telah mendorong masyarakat setempat untuk lebih berusaha untuk memecahkan permasalahan yang dihadapi (Sumaryo, 2011).

Sebagai gambaran makro, Perusahaan Air Minum Dalam Kemasan (PAMDK) telah beroperasi di Kabupaten Klaten sejak tahun 2003. Banyak kegiatan ekonomi yang telah berubah sebagai akibat dari beroperasinya PAMDK tersebut beserta program CSR yang dilakukan. PAMDK yang di Klaten merupakan salah satu perusahaan terbesar di Kabupaten Klaten. Hal ini dapat dilihat dari sumbangannya terhadap Pendapatan Asli Daerah (PAD) Kabupaten Klaten. Secara umum, sumbangan PAMDK terhadap PAD Kabupaten Klaten terus meningkat. Kontributor PAD penting yang lain adalah Perusahaan Daerah Air Minum (PDAM) Kota Surakarta yang mengambil air dari Kabupaten Klaten. Pada tahun 2012, PAD Kabupaten Klaten sebesar Rp 75,874 milyar. Kontribusi PAMDK Klaten sebesar Rp 12,570 milyar rupiah. Sementara, sumbangan PDAM Kota Surakarta sebesar 5 persen (Anonim, 2012).

Dampak ekonomi PAMDK bagi masyarakat sekitar berasal penciptaan lapangan pekerjaan. Keberadaan PAMDK di Klaten tidak terlepas dari peran serta masyarakat sekitar. Lapangan kerja langsung adalah terciptanya pekerjaan baru yang berhubungan langsung dengan proses bisnis PAMDK Klaten. Adapun kegiatan tersebut meliputi proses langsung di dalam perusahaan meliputi produksi, menejemen, pemasaran, tenaga bongkar muat, penyedia moda transportasi untuk distribusi produk, dan kegiatan lainnya. Hasil observasi menunjukkan bahwa sekitar $40 \%$ warga bekerja langsung pada PAMDK Klaten, yang terdiri dari $25 \%$ merupakan manajamen/staf/karyawan tetap perusahaan dan sekitar 20\% merupakan karyawan lepas perusahaan (Anonim, 2013).

Dampak tidak langsung meliputi kegiatan bisnis PAMDK Klaten berdampak pada terbukanya lapangan pekerjaan baru untuk memenuhi kebutuhan para pegawai/karyawan perusahaan tersebut. Munculnya lapangan kerja tidak langsung ini merupakan efek derivasi dari aktivitas suatu industri. Lapangan pekerjaan tidak langsung antara lain warung makan, toko kelontong besar dan kecil, penyediaan rumah pondokan bagi karyawan, jasa transpotasi lokal, sewa lahan parkir, tukang parkir, tambal ban dan bengkel.

Mengingat bahwa PADMK sudah lama beroperasi, maka perlu dikaji dampak keberadaan PADMK bagi masyarakat sekitar perusahaan. Selama ini belum ada kajian yang mendalam mengenai dampak ekonomi PADMK pada kehidupan masyarakat di sekitar perusahaan. Kajian ini bertujuan untuk menganalisis dampak ekonomi perusahaan terhadap kehidupan masyarakat di sekitar perusahaan.

\section{METODE PENELITIAN}

Penelitian ini dilakukan pada bulan MaretAgustus 2012. Lokasi penelitian ini adalah tiga desa di Kecamatan Polanharjo, Kabupaten Klaten. Penduduk Desa Ponggok dan Wangen mewakili masyarakat yang terkena dampak keberadaan perusahaan, baik langsung maupun tidak langsung. Penduduk Desa Janti yang terletak relatif jauh dari perusahaan mewakili masyarakat yang tidak terdampak. Dampak pembangunan dikelompokkan menjadi dampak langsung dan tidak langsung (Choliq dan Suwarna, 1999).

Teknik pengambilan sampel menggunakan purposive random sampling (Sugiyono, 2010). Sampel diambil dari populasi penduduk yang tidak dibedakan antara karyawan PADMK dan bukan karyawan. Dengan demikian, karyawan PADMK 
mempunyai kesempatan yang sama untuk diambil sebagai sampel. Syarat sampel adalah lokasi di sekitar perusahaan yang terkena dampak langsung, warga asli desa tersebut dan mengetahui keadaan sebelum dan sesudah perusahaan beroperasi, sudah menikah atau usia diatas 30 tahun. Jumlah sampel sebanyak 100 orang untuk setiap desa.

Penelitian ini menggunakan analisis difference in difference (Feder, dkk. 2004) agar terbebas dari selection bias. Penjelasan analisis difference in difference dapat dilihat pada Gambar 1. Pada Gambar 1, indikator dampak program adalah $Y$ pada sumbu tegak, dan $T$ menunjukkan waktu. Kurva dengan garis lurus mewakili masyarakat yang tidak terdampak, sedangkan kurva dengan garis putus-putus mewakili masyarakat yang terdampak. Pada kurun waktu $T_{0}-T_{1}, Y$ untuk kedua kelompok masyarakat tersebut berbeda. Kelompok yang tidak terdampak lebih tinggi dari pada kelompok yang terdampak. Keduanya mengalami laju kenaikan yang sama sampai dengan $T_{1}$. Pada saat $T_{1}$, yaitu saat dimulainya program terjadi perubahan $Y$ yang lebih cepat pada pada masyarakat terdampak dibandingkan dengan $Y$ pada masyarakat yang tidak berdampak. Perbedaan laju perubahan $Y$ pada kedua kelompok masyarakat tersebut merupakan akibat dari program. Secara matematis, model analisis tersebut dapat dirumuskan sebagai berikut:

$\hat{Y}=\frac{1}{Y} \frac{d Y}{d T}=\delta Y_{0}+\beta P+\alpha Z+u$

untuk $Y=$ indikator perubahan; $P=$ dampak program; $T=$ kurun waktu; $Z=$ faktor sosialekonomi yang dapat mempengaruhi laju pertumbuhan; $\delta$ laju pertumbuhan awal; $\beta=$ laju pertumbuhan akibat dampak program, $\alpha=$ koefisien dari faktor $Z$, u faktor lain yang tidak masuk dalam analisis. Interpretasi persamaan (1) adalah bahwa $Y$ pada saat $T$ tergantung pada $Y$ pada saat $T=0$ dengan laju pertumbuhan yang dipengaruhi oleh program dan faktor sosial-ekonomi. Pada kasus ini, $Y$ adalah pendapatan rumah tangga, sehingga pada persamaan (1), $\delta Y_{0}$ dimasukkan ke dalam model dengan logika bahwa pertumbuhan pendapatan sangat dipengaruhi oleh pendapatan awal (Mankiw dkk., 1992; Ram, 2007). Jika pendapatan awal semakin besar, maka akan menyebakan pertumbuhan semakin kecil, dan sebaliknya.

Indikator lain yang dianalisis adalah konsumsi rumah tangga dan investasi. Dua indikator tersebut merupakan implikasi dari perubahan pendapatan. Pada ekonomi rumah tangga, pendapatan yang diterima selanjutnya dibelanjakan untuk konsumsi dan investasi. Nicholson dan Synder (2011) menyebutkan konsumsi merupakan ukuran kesejahteraan. Peningkatan konsumsi sebagai

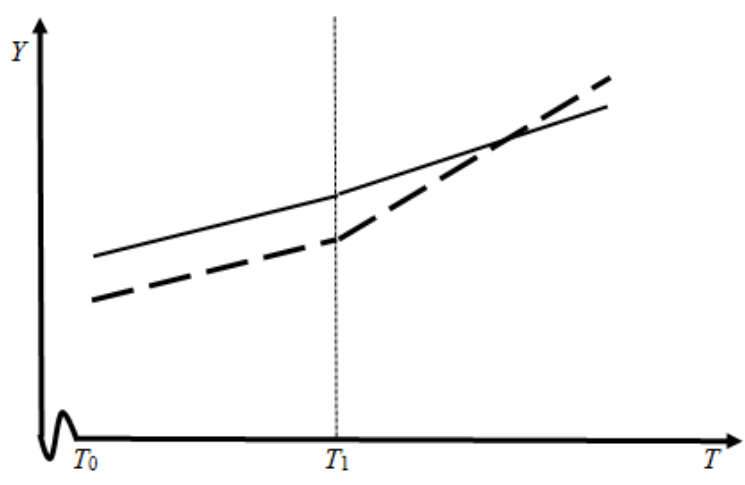

Gambar 1. Konsep difference in difference (Feder dkk., 2004).

akibat dari kenaikan pendapatan masyarakat mengindikasikan peningkatan kesejahteraan. Investasi, merupakan kegiatan untuk menahan konsumsi waktu sekarang untuk memperoleh pendapatan dan konsumsi yang lebih tinggi di masa mendatang. Perubahan pendapatan akan mengubah pola pengeluaran dari pendapatan itu sendiri.

Dengan masih mengikuti prosedur difference in difference, model konsumsi dirumuskan sebagai berikut:

$\hat{C}=\frac{1}{C} \frac{d C}{d T}=k+\varphi \hat{Y}+\delta C_{0}+\beta P+\alpha Z+u$

untuk $C=$ pengeluaran konsumsi, $P=$ dampak program; $T=$ kurun waktu; $Z=$ faktor sosialekonomi yang dapat mempengaruhi laju pertumbuhan konsumsi; $\delta$ laju pertumbuhan awal; $\beta=$ laju pertumbuhan akibat dampak program, $\alpha=$ koefisien dari faktor $Z, \mathrm{u}$ faktor lain yang tidak masuk dalam analisis. Dalam hal ini, konsumsi dipengaruhi oleh tingkat pertumbuhan pendapatan dan faktor-faktor lainnya. Seperti halnya pendapatan, pertumbuhan konsumsi dipengaruhi oleh konsumsi awal karena pola konsumsi biasanya juga tergantung pada konsumi awal. Jika konsumsi awal sudah tinggi, maka ada kecenderungan terjadi kenaikan yang lebih kecil, yang mencerminkan kejenuhan jika pendapatan meningkat tidak terlalu tinggi.

Analisis investasi dipakai untuk melengkapi pola pengeluaran sebagai akibat dari perubahan pendapatan keluarga. Dalam analisis ini, investasi yang diwujudkan dengan menyekolahkan anak dianalisis dengan menggunakan metode model logit, yaitu bahwa probabilitas keluarga untuk melakukan investasi dipengaruhi oleh pendapatan dan faktor sosial-ekonomi. Secara matematis, model logit dirumuskan sebagai berikut:

$\ln \frac{\{I=1\}}{\{I=0\}}=k+\delta \hat{Y}+\beta P+\alpha Z+u$

untuk $I=$ investasi, $\hat{Y}=$ pertumbuhan pendapatan keluarga. 
Jika koefisien bernilai positif, maka faktor tersebut menyebabkan kemungkinan terjadinya inventasi lebih besar, dan sebaliknya. Untuk melihat tingkat pengaruh faktor tersebut terhadap terjadinya investasi, maka dihitung efek marjinal yang mengukur besarnya dampak dari perubahan variabel bebas terhadap terjadinya investasi.

Untuk menelaah dampak program, akan lebih mudah untuk memahami tingkat pendapatan keluarga pada saat sebelum dan sesudah program pada wilayah yang terdampak langsung dan yang tidak terdampak dengan model sebagai berikut:

$Y_{T}=\gamma_{0}+\gamma_{1} P+\gamma_{2} Z+u$

$Y_{0}=\gamma_{0}+\gamma_{1} P+\gamma_{2} Z+u$

untuk $\mathrm{Y}_{\mathrm{T}}=$ pendapatan keluarga setelah program, dan $\mathrm{Y}_{0}=$ pendapatan keluarga sebelum program, $\gamma_{1}$ merupakan koefisien yang menunjukkan perbedaan antara daerah yang terdampak dan yang tidak terdampak. Jika $\gamma_{1}$ diketahui, maka akan dapat menjelaskan terjadinya perubahan pendapatan pada daerah yang terdampak dan yang tidak terdampak. Jika $\gamma_{2}$ dipaksakan sama dengan nol, akan diperoleh model perbandingan sederhana, yaitu hanya membandingkan pendapatan awal (dan pendapatan akhir) untuk wilayah yang terdampak dengan wilayah yang tak terdampak. Hal ini tentu saja menganggap faktor lainnya tidak penting. Untuk keperluan analisis, baik bentuk sederhana maupun yang diperluas semua diestimasi untuk mendukung model utama, yaitu peningkatan pendapatan keluarga.

Model analisis yang dirumuskan dalam bentuk persamaan (1) sampai dengan persamaan (5) diestimasi dengan analisis kuantitatif yang dilakukan dengan pendekatan ekonometrik. Uji statistik mengacu pada uji keseluruhan (uji $\mathrm{F}$ dan uji $\chi^{2}$ ) dan uji individual (uji t dan uji z). Analisis ekonometrik dilakukan dengan robust standard error untuk menghindari masalah heteroschedastisitas sehingga diperoleh hasil kesimpulan yang benar (Verbeek, 2002).

\section{Definisi dan Pengukuran Variabel}

Dari hasil wawancara telah diperoleh banyak informasi. Tetapi hanya beberapa variabel terpilih sesuai dengan analisis kuantitatif ini. Definisi dan pengukuran variabel disajikan pada Tabel 1 .

\section{HASIL DAN PEMBAHASAN}

Gambaran demografis dan pendidikan responden penelitian disajikan pada Tabel 2. Di Desa Ponggok dan Wangen, sebagian besar penduduk masuk pada kelompok usia 36-55 tahun, sedangkan Desa Janti sebagian besar penduduk berusia lebih dari 55 tahun. Perbedaan yang terlihat adalah penduduk di Desa Wangen dan Ponggok sebagian besar masih pada usia produktif.

Berdasarkan tingkat pendidikan, $70 \%$ penduduk telah menyelesaikan pendidikan tingkat SLPT ke atas. Bahkan sekitar $15 \%$ penduduk mempunyai pendidikan setara perguruan tinggi. Hal ini menggambarkan kualitas sumber daya manusia di tiga desa tersebut sudah cukup baik.

Model pertumbuhan pendapatan keluarga diestimasi menggunakan dua pendekatan, yaitu tanpa konstanta dan dengan konstanta. Hasilnya disajikan pada Tabel 3. Pada model 1, tanpa konstanta, secara keseluruhan sangat signifikan dengan nilai $\mathrm{R}^{2}$ cukup tinggi yaitu 0,53 , yang artinya bahwa kira-kira 53\% variasi pertumbuhan

Tabel 1. Definisi dan pengukuran variabel terpilih.

\begin{tabular}{|c|c|c|}
\hline Variabel & Deskripsi & Ukuran \\
\hline \multicolumn{3}{|l|}{ Variabel indikator: } \\
\hline $\begin{array}{l}\text { Pertumbuhan } \\
\text { pendapatan }\end{array}$ & $\begin{array}{l}\text { Pendapatan akhir dikurangi pendapatan awal, dibagi } \\
\text { pendapatan awal, kali } 100 \%\end{array}$ & Persen $(\%)$ \\
\hline $\begin{array}{l}\text { Pertumbuhan } \\
\text { komsumsi }\end{array}$ & $\begin{array}{l}\text { Konsmsi akhir dikurangi konsumsi awal, dibagi } \\
\text { konsumsi awal, kali } 100 \%\end{array}$ & Persen $(\%)$ \\
\hline Keputusan investasi & $\begin{array}{l}\text { Keputusan dalam melakukan investasi dalam bentuk } \\
\text { pendidikan anak }\end{array}$ & Dummy, 1 jika ya \\
\hline Pendapatan awal & Pendapatan sebelum perusahaan ada & Rupiah \\
\hline Pendapatan akhir & Pendapatan setelah perusahaan ada & Rupiah \\
\hline \multicolumn{3}{|l|}{ Variabel penjelas: } \\
\hline Wilayah terdampak & $\begin{array}{l}\text { Wilayah yang terkena dampak langsung oleh } \\
\text { keberadaan perusahaan }\end{array}$ & Dummy, 1 jika ya \\
\hline Sekolah & $\begin{array}{l}\text { Tingkat pendidikan formal yang dicapai oleh kepala } \\
\text { keluarga }\end{array}$ & $\begin{array}{l}1=\text { tidak lulus SD, } 2=\mathrm{SD}, 3 \\
=\mathrm{SMP}, 4=\mathrm{SMA}, 5=\mathrm{PT}\end{array}$ \\
\hline Usiar & Usia kepala keluarga saat diwawancarai & tahun \\
\hline Status pernikahan & Status pernikahan pada saat diwawancarai & Dummy $=1$ jika belum nikah \\
\hline Jender & Jelas kelamin kepala keluarga & Dummy $=1$ jika wanita \\
\hline Jumlah anak & Jumlah anak yang menjadi tanggungan keluarga & Orang \\
\hline Lama domisili & Lama tinggal di wilayah kajian & Tahun \\
\hline
\end{tabular}


Tabel 2. Karakteristik responden berdasarkan usia dan tingkat pendidikan.

\begin{tabular}{|c|c|c|c|c|c|c|c|c|}
\hline \multirow[t]{2}{*}{ Kategori } & \multirow[t]{2}{*}{ No } & \multirow[t]{2}{*}{ Kelompok } & \multicolumn{2}{|c|}{ Desa Ponggok } & \multicolumn{2}{|c|}{ Desa Wangen } & \multicolumn{2}{|c|}{ Desa Janti } \\
\hline & & & Jumlah & $(\%)$ & Jumlah & $(\%)$ & Jumlah & $(\%)$ \\
\hline \multirow[t]{5}{*}{ Usia } & 1 & $17-25$ Tahun & 3 & $3 \%$ & 4 & $4 \%$ & 4 & $4 \%$ \\
\hline & 2 & $26-35$ Tahun & 14 & $14 \%$ & 22 & $22 \%$ & 2 & $2 \%$ \\
\hline & 3 & $36-45$ Tahun & 38 & $38 \%$ & 31 & $31 \%$ & 8 & $8 \%$ \\
\hline & 4 & $46-55$ Tahun & 20 & $20 \%$ & 23 & $23 \%$ & 13 & $13 \%$ \\
\hline & 5 & $>55$ Tahun & 25 & $25 \%$ & 20 & $20 \%$ & 73 & $73 \%$ \\
\hline \multirow[t]{5}{*}{ Pendidikan } & 1 & Tidak lulus SD & 1 & $1 \%$ & 5 & $5 \%$ & 2 & $2 \%$ \\
\hline & 2 & Lulus SD & 18 & $18 \%$ & 23 & $23 \%$ & 16 & $16 \%$ \\
\hline & 3 & Lulus SLTP & 21 & $21 \%$ & 17 & $17 \%$ & 15 & $15 \%$ \\
\hline & 4 & Lulus SLTA & 45 & $45 \%$ & 41 & $41 \%$ & 48 & $48 \%$ \\
\hline & 5 & Lulus PT & 15 & $15 \%$ & 14 & $14 \%$ & 19 & $19 \%$ \\
\hline
\end{tabular}

Tabel 3. Hasil estimasi model pertumbuhan pendapatan keluarga.

\begin{tabular}{|c|c|c|c|c|}
\hline \multirow[b]{2}{*}{ Variabel } & \multicolumn{2}{|c|}{ Model-1 } & \multicolumn{2}{|c|}{ Model-2 } \\
\hline & Koefisien & $\mathrm{t}$ & Koefisien & $\mathrm{t}$ \\
\hline Konstanta & -- & -- & 45,90 & $0,57^{\mathrm{n}}$ \\
\hline Pendapatan awal & $-0,10$ & $-5,99^{a}$ & $-0,10$ & $-5,92^{\mathrm{a}}$ \\
\hline Terdampak & 124,30 & $4,97^{\mathrm{a}}$ & 121,41 & $4,79^{\mathrm{a}}$ \\
\hline Sekolah & 75,59 & $6,26^{\mathrm{a}}$ & 71,43 & $4,73^{\mathrm{a}}$ \\
\hline Usia & $-0,11$ & $-0,10^{\mathrm{n}}$ & $-0,364$ & $-0,30^{\mathrm{n}}$ \\
\hline Belum nikah & $-41,54$ & $-0,73^{n}$ & $-49,11$ & $-0,87^{\mathrm{n}}$ \\
\hline Wanita & $-18,66$ & $-0,54^{\mathrm{n}}$ & $-22,03$ & $-0,62^{n}$ \\
\hline Jumlah anak & 30,15 & $2,25^{\mathrm{b}}$ & 29,91 & $2,24^{\mathrm{b}}$ \\
\hline Lama domisili & $-27,76$ & $-2,37^{\mathrm{b}}$ & $-31,27$ & $-2,34^{b}$ \\
\hline Observasi & 300 & & 300 & \\
\hline F-hitung & $34,13^{\mathrm{a}}$ & & $8,07^{\mathrm{a}}$ & \\
\hline $\mathrm{R}^{2}$ & 0,53 & & 0,25 & \\
\hline
\end{tabular}

Variabel terikat: pertumbuhan pendapatan keluarga. ${ }^{\mathrm{a}}$ ) nyata pada kesalahan $1 \%{ }^{\mathrm{b}}$ ) nyata pada kesalahan $5 \%,{ }^{\mathrm{n}}$ ) tidak nyata.

faktor lain yang tidak tercatat dan tidak dapat dikendalikan.

Model dengan konstanta, juga sangat signifikan, tetapi menunjukkan $\mathrm{R}^{2}$ yang lebih rendah yaitu 0,25 . Namun nilai konstanta tersebut tidak nyata, atau secara statistik nilainya sama dengan nol. Jadi untuk model pertumbuhan pendapatan keluarga yang dipakai adalah model 1 . Fokus analisis adalah dampak keberadaan PAMDK. Oleh karena itu faktor yang ditelaah lebih dulu adalah daerah yang terdampak. Model 1 menunjukkan bahwa daerah yang terdampak memiliki koefisien yang sangat nyata. Hal ini menunjukkan bahwa tingkat pertumbuhan pendapatan keluarga di wilayah yang terdampak lebih tinggi daripada tingkat pertumbuhan pendapatan keluarga di wilayah yang tidak terdampak. Secara kuantitatif, tingkat pertumbuhan pendapatan keluarga di wilayah terdampak lebih tinggi sebesar 120 satuan. Tingkat pertumbuhan yang lebih tinggi pada wilayah yang terkena dampak dapat terjadi karena kesempatan kerja yang lebih banyak, dan faktor-faktor lain sebagai effek pengganda yang disebabkan oleh keberadaan perusahaan di lokasi tersebut.

Faktor-faktor lain yang juga berperan nyata dalam perubahan pertumbuhan adalah pendapatan awal, tingkat pendidikan, jumlah anak, dan lama domisili. Pendapatan awal mempunyai pengaruh negatif, artinya bahwa semakin tinggi pendapatan awal menyebabkan tingkat pertumbuhan lebih lambat. Ini masuk akal karena semakin sulit untuk meningkatkan pendapatan jika pendapatan sudah tinggi, sebaliknya jika pendapatan masih rendah, maka akan lebih mudah untuk meningkatkan pendapatan. Sekolah berdampak positif. Ini sangat logis, karena dengan pendidikan yang lebih tinggi akan semakin mudah memperoleh pekerjaan yang lebih baik. Pegawai dengan pendidikan yang lebih tinggi juga akan mendapat insentif untuk kenaikan jabatan pada instansi yang resmi. Jumlah anak menunjukkan nilai positif. Keadaan ini masih dapat diterima karena semakin banyak jumlah anak akan semakin banyak usaha yang dilakukan untuk menambah pendapatan. Lama domisili mempunyai nilai negatif. Jika lama domisili dapat dikatakan lebih mapan, maka keadaan ini menunjukkan bahwa orang yang sudah mapan sudah merasa cukup dan tidak terlalu mengejar pendapatan. Berbeda dengan yang baru datang, mereka masih berusaha mencari rejeki yang lebih baik di tempat yang baru.

Analisis selanjutnya adalah perubahan pola konsumsi. Kenaikan pendapatan keluarga akan mempengaruhi belanja yang berupa konsumsi dan investasi keluarga. Tabel 4 merupakan hasil 
estimasi model konsumsi keluarga. Model perubahan konsumsi keluarga juga diestimasi dengan dua model yaitu dengan konstanta dan tanpa konstanta. Kedua model tersebut sangat signifikan. Dalam hal ini, konstanta menunjukkan hasil yang nyata sehingga model 1 dijadikan dasar analisis. Secara umum, terjadi pertumbuhan konsumsi di semua wilayah, baik yang terdampak maupun yang tidak terdampak. Tidak ada perbedaan yang nyata antara wilayah yang terdampak dan yang tidak terdampak dalam hal pertumbuhan konsumsi keluarga. Hal ini bukan sesuatu yang buruk, karena konsumsi bukan satusatunya ukuran kesejahteraan. Untuk saat ini tingkat konsumsi yang tidak berbeda secara nyata karena terjadi penghematan atau investasi untuk memperoleh konsumsi yang lebih tinggi pada masa yang akan datang. Peningkatan konsumsi keluarga terjadi secara nyata sebagai akibat dari peningkatan pendapatan. Jika di daerah yang terdampak menunjukkan laju peningkatan pendapatan yang lebih tinggi, maka secara tidak langsung, sebenarnya konsumsi keluarga di wilayah terdampak juga meningkat.
Seperti pada pendapatan, pertumbuhan konsumsi akan lebih rendah jika konsumsi awal lebih tinggi. Satu alasan yang mudah dipahami pada tingkat konsumsi yang tinggi yaitu sudah terjadi kejenuhan. Usia, status pernikahan, jumlah anak dan lama domisili tidak mempengaruhi konsumsi keluarga secara nyata. Artinya, baik tua maupun muda, nikah maupun belum nikah, jumlah anak sedikit atau banyak, dan sudah lama atau masih baru berdomisili mempunyai tingkat pertumbuhan konsumsi yang sama. Hal yang menarik adalah bahwa rumah tangga yang dikepalai oleh wanita menunjukkan kenaikan konsumsi yang nyata dibandingkan dengan rumah tangga yang dikepalai oleh pria. Hal ini menunjukkan bahwa wanita lebih konsumtif. Keadaan ini sesuai dengan gejala sosial yang sudah umum.

Selain konsumsi, investasi juga merupakan akibat dari peningkatan pendapatan keluarga. Pendapatan yang tidak dikonsumsi mungkin akan diinvestasikan. Tabel 5 merupakan hasil estimasi model probabilitas investasi. Model secara keseluruhan terlihat sangat signifikan. Tidak ada

Tabel 4. Hasil estimasi model pertumbuhan konsumsi keluarga.

\begin{tabular}{|c|c|c|c|c|}
\hline & \multicolumn{2}{|c|}{ Model-1 } & \multicolumn{2}{|c|}{ Model-2 } \\
\hline & Koefisien & $\mathrm{t}$ & Koefisien & $\mathrm{t}$ \\
\hline Konstanta & 147,65 & $1,51^{\mathrm{c}}$ & & \\
\hline Konsumsi awal & $-0,0003$ & $-4,16^{\mathrm{a}}$ & $-0,0003$ & $-4,33^{\mathrm{a}}$ \\
\hline Terdampak & $-22,50$ & $-0,67^{n}$ & $-13,48$ & $-0,39^{n}$ \\
\hline Pertumbuhan pendapatan & 0,404 & $3,02^{\mathrm{a}}$ & 0,405 & $3,04^{\mathrm{a}}$ \\
\hline Sekolah & 37,10 & $2,46^{\mathrm{a}}$ & 50,38 & $4,53^{\mathrm{a}}$ \\
\hline Usia & $-0,298$ & $-0,22^{\mathrm{n}}$ & 0,517 & $0,36^{\mathrm{n}}$ \\
\hline Belum nikah & 27,53 & $0,31^{\mathrm{n}}$ & 51,90 & $0,59^{\mathrm{n}}$ \\
\hline Wanita & 92,67 & $2,07^{\mathrm{b}}$ & 103,52 & $2,38^{\mathrm{b}}$ \\
\hline Jumlah anak & 4,82 & $0,45^{\mathrm{n}}$ & 5,57 & $0,51^{\mathrm{n}}$ \\
\hline Lama domisili & $-12,27$ & $-0,62^{\mathrm{n}}$ & $-0,877$ & $-0,05^{\mathrm{n}}$ \\
\hline Observasi & 300 & & 300 & \\
\hline F-hitung & $6,57^{\mathrm{a}}$ & & $23,70^{\mathrm{a}}$ & \\
\hline $\mathrm{R}^{2}$ & 0,28 & & 0,49 & \\
\hline
\end{tabular}

Variabel terikat: pertumbuhan konsumsi keluarga. ${ }^{a}$ ) nyata pada kesalahan $1 \%,{ }^{b}$ ) nyata pada kesalahan $5 \%,{ }^{c}$ ) nyata pada kesalahan $10 \%,{ }^{\mathrm{n}}$ ) tidak nyata.

Tabel 5. Hasil estimasi model investasi pendidikan anak.

\begin{tabular}{lllll}
\hline \multirow{2}{*}{ Variabel } & \multicolumn{2}{c}{ Logit } & \multicolumn{2}{c}{ Efek marginal } \\
\cline { 2 - 5 } & Koefisien & $\mathrm{Z}$ & nilai & $\mathrm{Z}$ \\
\hline Konstanta & 3,044 & $2,35^{\mathrm{b}}$ & - & - \\
Terdampak & $\mathbf{0 , 4 4 8}$ & $\mathbf{1 , 3 2 ^ { \mathbf { n } }}$ & $\mathbf{0 , 0 6 6}$ & $\mathbf{1 , 2 6 ^ { \mathbf { n } }}$ \\
Pertumbuhan pendapatan & 0,003 & $2,67^{\mathrm{a}}$ & 0,001 & $3,00^{\mathrm{a}}$ \\
Usia & $-0,064$ & $-4,17^{\mathrm{a}}$ & $-0,009$ & $-4,28^{\mathrm{a}}$ \\
Wanita & $-0,741$ & $-1,85^{\mathrm{b}}$ & $-0,122$ & $-1,61^{\mathrm{c}}$ \\
Jumlah anak & 0,277 & $2,12^{\mathrm{b}}$ & 0,039 & $2,14^{\mathrm{b}}$ \\
Belum nikah & $-2,725$ & $-3,66^{\mathrm{a}}$ & $-0,581$ & $-4,11^{\mathrm{a}}$ \\
Sekolah & 0,219 & $1,44^{\mathrm{c}}$ & 0,031 & $1,43^{\mathrm{c}}$ \\
Lama domisili & $-0,133$ & $-0,63^{\mathrm{n}}$ & $-0,019$ & $-0,64^{\mathrm{n}}$ \\
\hline Observasi & 300 & & & \\
$\chi^{2}$-hitung & $55,79^{\mathrm{a}}$ & & & \\
Log-likelihood & $-133,89$ & & & \\
\hline Variabel terikat: investasi atau tidak; $\left.{ }^{\mathrm{a}}\right)$ nyata pada kesalahan $1 \%$; $^{\mathrm{b}}$ ) nyata pada kesalahan $5 \%$; $^{\mathrm{n}}$ ) tidak nyata.
\end{tabular}


Tabel 6. Perbandingan pendapatan keluarga sebelum dan sesudah.

\begin{tabular}{|c|c|c|c|c|c|c|c|c|}
\hline \multirow{4}{*}{ Variabel } & \multicolumn{8}{|c|}{ Pendapatan keluarga } \\
\hline & \multicolumn{4}{|c|}{ Analisis sederhana } & \multicolumn{4}{|c|}{ Analisis diperluas } \\
\hline & \multicolumn{2}{|c|}{ Sebelum } & \multicolumn{2}{|c|}{ Sesudah } & \multicolumn{2}{|c|}{ Sebelum } & \multicolumn{2}{|c|}{ Sesudah } \\
\hline & Koef & $\mathrm{t}$ & Koef & $\mathrm{t}$ & Koef & $\mathrm{t}$ & Koef & $\mathrm{t}$ \\
\hline Konstanta & 787000 & $12,73^{\mathrm{a}}$ & 1364500 & $11,87^{\mathrm{a}}$ & -47949 & $-0,17^{\mathrm{n}}$ & -239846 & $-0,63^{n}$ \\
\hline Terdampak & -187075 & $-2,55^{a}$ & 44350 & $0,34^{n}$ & -143597 & $-1,84^{b}$ & 173415 & $1,37^{n}$ \\
\hline Sekolah & & & & & 143509 & $3,46^{\mathrm{a}}$ & 392783 & $6,41^{\mathrm{n}}$ \\
\hline Usia & & & & & 3987 & $1,25^{\mathrm{n}}$ & 3053 & $0,58^{\mathrm{n}}$ \\
\hline Belum nikah & & & & & 75379 & $0,59^{n}$ & 301300 & $0,73^{\mathrm{n}}$ \\
\hline Wanita & & & & & 12689 & $0,16^{\mathrm{n}}$ & -144925 & $-0,95^{\mathrm{n}}$ \\
\hline Jumlah anak & & & & & 36195 & $1,11^{\mathrm{n}}$ & 109903 & $2,2^{\mathrm{b}}$ \\
\hline Lama domisili & & & & & 8796 & $0,23^{\mathrm{n}}$ & -49056 & $-0,84^{\mathrm{n}}$ \\
\hline Observasi & 300 & & 300 & & 300 & & 300 & \\
\hline F-hitung & $6,52^{\mathrm{a}}$ & & $0,7341^{\mathrm{n}}$ & & $3,24^{\mathrm{a}}$ & & $7,88^{\mathrm{a}}$ & \\
\hline $\mathrm{R}^{2}$ & 0,02 & & 0,0005 & & 0,09 & & 0,18 & \\
\hline
\end{tabular}

Variabel terikat: pendapatan; ${ }^{a}$ ) nyata pada kesalahan $1 \% ;{ }^{b}$ ) nyata pada kesalahan $5 \% ;{ }^{n}$ ) tidak nyata.

perbedaan yang nyata antara wilayah yang terdampak dan yang tidak terdampak dalam hal probabilitas terjadinya investasi, namun ada tendensi yang lebih tinggi untuk wilayah yang terdampak. Probabilitas terjadinya investasi terjadi ketika pendapatan keluarga meningkat. Mengingat di wilayah yang terdampak pedapatan keluarga meningkat secara signifikan, maka kondisi tersebut secara tidak langsung menunjukkan bahwa di wilayah terdampak telah terjadi investasi yang lebih tinggi.

Usia menunjukkan pengaruh yang negatif, artinya semakin tua, kecenderungan investasi lebih rendah. Hal ini mudah dimengerti karena jika sudah tua, maka semua anak-anak sudah selesai sekolah. Wanita menunjukkan probabilitas terjadinya investasi yang lebih rendah dibandingkan pria. Ada kemungkinan bahwa para wanita tersebut sudah tua, atau janda, sehingga mereka tidak perlu melakukan investasi. Jumlah anak berpengaruh positif terhadap investasi. Fenomena ini sangat logis karena investasi ini adalah dalam bentuk pendidikan anak. Oleh karena itu semakin banyak jumlah anak, probabilitas terjadinya investasi juga semakin tinggi. Kondisi ini sejalan dengan keadaan bahwa status yang belum nikah menunjukkan probabilitas yang rendah. Tingkat pendidikan kepala keluarga mempengaruhi probabilitas terjadinya investasi secara positif dan nyata. Belajar dari pengalaman bahwa tingkat pendidikan yang lebih tinggi dapat meningkatkan pendapatan, maka orang tua dengan pendidikan yang lebih tinggi akan melakukan investasi pendidikan bagi anak-anaknya. Lama domisili tidak berpengaruh nyata, artinya baik sudah lama atau baru berdomisili menunjukkan tingkat probabilitas yang sama dalam hal investasi pendidikan anak.

Jika dilihat dari efek marjinal, maka faktor yang paling penting dalam mempengaruhi terjadinya investasi adalah jenis kelamin dan status pernikahan. Implikasinya bahwa pria yang berpendidikan setelah menikah dan punya anak akan melakukan investasi dalam bentuk pendidikan bagi anak-anak yang diasuh. Keadaan tersebut akan diperkuat jika mereka berada di wilayah yang terdampak.

Untuk memperkuat bukti bahwa telah terjadi perubahan pendapatan keluarga di wilayah yang terdampak dan yang tidak terdampak, pendapatan keluarga sebelum dan sesudah perusahaan perlu dibandingkan. Hasilnya disajikan pada Tabel 6.

Pada analisis sederhana, pendapatan keluarga di wilayah terdampak sebelum perusahaan ada secara nyata lebih rendah dari pada pendapatan keluarga di daerah yang tidak terdampak. Kondisi ini menunjukkan keadaan awal yang berbeda. Namun, setelah ada perusahaan, kondisi tersebut berubah. Pendapatan keluarga di wilayah yang terdampak dan yang tidak terdampak tidak menujukkan perbedaan yang nyata. Pada analisis yang diperluas, yaitu setelah dimasukkan variabelvariabel kontrol, keadaan tersebut masih konsisten. Jadi, keberadaan perusahaan telah memberikan manfaat bagi masyarakat dalam mengejar ketinggalan dari daerah lain yang mempunyai tingkat pendapatan yang lebih tinggi. Kondisi ini mendukug analisis bahwa telah terjadi pertumbuhan pendapatan keluarga yang lebih cepat pada daerah yang terdampak, sehingga dapat mengejar ketinggalan dan menyamai tingkat pendapatan keluarga di wilayah lainnya.

Secara ekonomi, keberadaan PAMDK di Klaten telah mengahasilkan multiplier effect bagi masyarakat sekitar. Masyarakat di sekitar telah mampu memanfaatkan potensi ekonomi yang dapat meningkatkan pendapatan, yang selanjutkan dapat meningkatkan kesejahteraan. Namun demikian, tidak berarti bahwa keberaadaan PAMDK dapat beroperasi secara tidak terbatas dalam mengeksploitasi sumberdaya air. Sumberdaya air 
merupakan kebutuhan pokok bagi masyarakat, baik untuk keperluan rumah-tangga sehari-hari dan sebagai sumberdaya yang digunakan untuk kegiatan ekonomi lainnya, yaitu pertanian dan perikanan. Oleh karena itu perusahaan masih wajib bertanggung jawab dalam konservasi lingkungan untuk menjaga kelestarian sumberdaya air tersebut. Jika tidak, maka masyarakat akan dirugikan karena sumberdaya air akan tidak akan mampu mencukupi kebutuhan dasar seiring dengan peningkatan kebutuan air di masa mendatang. Darmanto dan Sudarmadji (2013) menyarankan agar pengelolaan sumberdaya air melibatkan masyarakat. Dalam pemeliharaan dikedepankan asas kegotongroyongan tanpa mengabaikan budaya masyarakat setempat. Dampak sosial yang mungkin muncul adalah jumlah pendatang yang meningkat dan terkonsentrasi di sekitar perusahaan dan cenderung tidak teratur. Partini (2013) menyarankan agar perusahaan memperhatikan masalah ini melalui program CSR.

\section{KESIMPULAN}

Keberadaan PAMDK di Klaten telah memberi eksternalitas positif bagi masyarakat. Berbagai program dan effek pengganda ekonomi dalam bentuk penciptaan kesempatan dan lapangan kerja bagi masyarakat sekitar sudah pasti akan meningkatkan pendapatan dan taraf hidup masyarakat di wilayah yang terdampak langsung. Dengan menggunakan model pertumbuhan pendapatan keluarga, telah terbukti secara nyata bahwa keberadaan perusahaan dengan segala program-program yang ada telah mampu meningkatkan pendapatan keluarga yang bertempat di sekitar perusahaan. Keadaan keluarga yang sebelumnya jauh tertinggal, mampu mengejar dan menyamai tingkat pendapatan keluarga di wilayah lain yang lebih dulu tinggi.

Sebagai akibat dari peningkatan pendapatan yang lebih cepat, secara langsung maupun tidak langsung telah meningkatkan konsumsi dan memicu terjadinya investasi dalam bentuk pendidikan anak. Konsumsi merupakan salah satu ukuran kesejahteraan, namun demikian konsumsi yang berlebihan yang tidak disertai investasi, yang dalam hal ini pendidikan, bukan merupakan dampak yang diharapkan.

Secara umum, keberadaan perusahaan telah memberi manfaat ekonomi bagi masyarakat sekitarnya. Namun perlu diingat bahwa sumberdaya air merupakan kebutuhan pokok masyarakat untuk kehidupan dan kegiatan ekonomi lainnya. Perusahaan bertanggung jawab untuk tetap melestarikannya sehingga tidak merugikan masyarakat di kemudian hari.

\section{DAFTAR PUSTAKA}

Anonim, 2006. Corporate Governance, Institute of Company Secretaries of India, New Delhi.

Anonim, 2012. Dinas Pengelolaan Pendapatan Keuangan dan Aset, Kabupaten Klaten dan Dirjen Perimbangan Keuangan, Kementerian Keuangan RI, Jakarta.

Anonim, 2013. Kajian Dampak Multi Dimensi Kegiatan Bisnis PT Tirta Investama Klaten (Aqua Danone) di Desa Ponggok dan Wangen, Kecamatan Polanharjo, Kabupaten Klaten, Provinsi Jawa Tengah. Fakultas Ekonomi, Universitas Sebelas Maret, Surakarta.

Chahoud, T., dan Emmerling, J., 2006. Corporate Social and Environmental Responsibility in India, UN Global Compact's Role, pp. 12.

Choliq, A.R., dan Suwarna, H., 1999. Evaluasi Proyek (Suatu Pengantar), Pionir Jaya, Bandung.

Comincioli, N., Poddi, L., dan Vergalli, S., 2012. Does Corporate Social Responsibility Affect The Performance Of Firm? Economy and Society Series, 53:1-33.

Darmanto, D., dan Sudarmadji, 2013. Pengelolaan Sungai Berbasis Masyarakat Lokal, di Daerah Lereng Selatan Gunung Api Merapi, Jurnal Manusia dan Lingkungan, 20(2):229-239.

Feder, G., Murgai, R. dan Quizon, J.B., 2004. Sending Farmers Back to Schools: The Impact of Farmer Field School in Indonesia. Review of Agricultural Economics, 26(1):45-62.

Gunawan, B. dan Utami, S.S., 2008. Peranan Corporate Social Responsibility Dalam Nilai Perusahaan. Jurnal Akuntansi dan Keuangan, 7(2):174-185.

Kotler, P., dan Lee, N., 2005. Corporate Social Responsibility: Doing the Most Good for Your Company and Your Cause. John Wiley \& Sons, New Jersey.

Mankiw, N.G., Romer, D., dan Weil, D.N., 1992. Contribution to The Empirics of Economic Growth, Quarterly Journal of Economics, 107(2):407-437.

Meutia, R., 2005. Tingkat Kepedulian dan Tanggung Jawab Sosial Perusahaan Terhadap Nilai Perusahaan: Studi Empiris Pada Perusahaan Manufaktur di Provinsi Nanggroe Aceh Darussalam. Jurnal E-Mabis, 1(11):1-20.

Nicholson, W. dan Synder, C.M., 2011. Microeconomic Theory: Basic Principles and Extensions. Chengage Learning SouthWestern, Mason.

Partini, 2013. CSR dan Pemberdayaan Masyarakat (Studi Implementasi CSR-PTBA di Muara Enim, Sumatra Selatan), Jurnal Manusia dan Lingkungan, 20(2):84-99. 
Prayogo, D., dan Hilarus, Y., 2012. Efektivitas Program CSR/CD dalam Pengentasan Kemiskinan: Studi Peran Perusahaan Geotermal di Jawa Barat, Jurnal Sosiologi Masyarakat, 17(1):1-22.

Ram, R., 2007. IQ and Economic Growth: Further Augmentation of Mankiw-Romer-Weil Model, Economics Letters, 94:7-11.

Soesilowati, E., Indriyanti, D.R., dan Widiyanto, 2011. Model Corporate Social Responsibility Dalam Program Pemberdayaan Petani
Hortikultura, Jurnal Ekonomi Pembangunan, 12(1):102-117.

Sugiyono, 2010. Metode Penelitian Kuantitatif Kualitatif dan $R \& D$. Alfabeta, Bandung.

Sumaryo, 2011. Tanggung Jawab Sosial Perusahaan dan Tingkat Keberdayaan Ekonomi Rumah Tangga, Jurnal Ekonomi Pembangunan, 12(2):272-280.

Verbeek, M., 2002. A Guide to Modern Econometrics. John Wiley \& Sons, Chichester. 